\title{
Cognition as expression: On the autopoietic foundations of an aesthetic theory of nature
}

\author{
Andreas Weber \\ Institute for Cultural Studies, Humboldt-Universität zu Berlin \\ Sophienstraße 22a, D-10178 Berlin, Germany ${ }^{1}$ \\ e-mail: andreas.weber@rz.hu-berlin.de
}

In memoriam Francisco J. Varela

\begin{abstract}
This paper attempts to put forward an aesthetic theory of nature based on a biosemiotic description of the living, which in turn is derived from an autopoietic theory of organism (F. Varela). An autopoietic system's reaction to material constraints is the unfolding of a dimension of meaning. In the outward Gestalt of autopoietic systems, meaning appears as form, and as such it reveals itself in a sensually graspable manner. The mode of being of organisms has an irreducible aesthetic side in which this mode of being becomes visible. Nature thus displays a kind of transparency of its own functioning: in a nondiscursive way organisms show traces of their conditio vitae through their material self-presentation. Living beings hence always show a basic level of expressiveness as a necessary component of their organic mode of being. This is called the ecstatic dimension of nature (G. Böhme, R. Corrington). Autopoiesis in its full consequence then amounts to a view reminding of Paracelsus' idea of the signatura rerum (C. Glacken, H. Böhme): nature is transparent, not because it is organized digitally as a linguistic text or code, but rather because it displays analogically the kind of intentionality engendered by autopoiesis. Nature as a whole, as "living form" (S. Langer), is a symbol for organic intentionality. The most fundamental meaning of nature protection thus is to guarantee the "real presence" of our soul.
\end{abstract}

\footnotetext{
${ }^{1}$ Private Address: D-21720 Guderhandviertel 90, Germany.
} 
A summer, with its harvest sown, reaped and stored, is an epic song ...

R. W. Emerson

\section{Introduction}

We live in a time that is witnessing great progress in the field of biology. Yet, in spite of being able to engineer new qualities in living beings, biology remains unable to define its object of study: life (Kull 1999). Theoretical advances in this area have not gone much further than when Schrödinger (1944) published his landmark paper on the subject. Biologists can enumerate certain qualities of the living motility, irritability, perception and so forth - but cannot define what life really is.

At the same time, it is no longer clear what we mean by nature, nor if nature as an independent domain exists at all. Many believe that what we conceive of as "nature" is a human invention that can only be understood from a specific cultural background. This view is called the "cultural a priori" (Böhme et al. 2000). Culture, on the other hand, is thought to obey only the laws of the free, arbitrary, and glottomorphic human mind. But as observers such as George Steiner (1991) note, products that emerge from such a conception of culture are suffering from an acute breakdown of sense.

This situation coincides with the global destruction of biodiversity, the pace of which is still increasing, if slower than before (Wilson 1995). This coincidence is not without reason. It is the outcome of the current presupposition of "what life really is", which acts as a kind of hidden center of gravity at the core of our culture: it is the metaphor of the organic machine, or as Hans Jonas (1973) puts it, the overwhelming dominance of an ontology of death.

In the following, I first sketch an alternative approach to defining life, drawn mainly from the theory of autopoiesis. On this basis, I try to demonstrate that the realization of life always includes an expressive aspect. I argue that, from an autopoietic point of view, the organism is embodied cognition; hence, its outward shape is a sign of its inner perspective. Because nature in this view is symbolic and expressive also of human feeling, its destruction amounts to a reduction of human inner experience. 


\section{Life as embodied identity}

To overcome the threefold dilemma described above requires a new understanding of life. One stream of thought that can lead to such an understanding is the theory of autopoiesis, and particularly its development by Francisco Varela. He provides a basic, but non-substantive definition of life. "An organism", he says, "is fundamentally a process of constitution of an identity" (Varela 1997). A living entity produces itself and all its components independently. It is distinguished by the ability to retain its integrity in the face of its environment. It produces the structure as well as the border of its milieu. Thus, the organism produces exactly the components that have produced it. It is important to see that the living entity exists as a certain self-identical structure in space and time, although it is at no moment materially identical with itself. Only the fact of being alive keeps this circuit closed. When an organism dies, the process comes to an end, and the components behave as normal chemical compounds - they decay:

An autopoietic system - the minimal living organization - is one that continuously produces the components that specify it, while at the same time realizing it (the system) as a concrete unity in space and time, which makes the network of production of components possible. More precisely defined: An autopoietic system is organized (defined as unity) as a network of processes of production (synthesis and destruction) of components such that these components (i) continuously regenerate the network that is producing them, and (ii) constitute the system as a distinguishable unity in the domain in which they exist. (Varela 1997: 75)

The organization of the living is characterized by the conjunction of two, seemingly different ontological realms. Unshaped matter and the process of regulation together make up the proper reality of the organism. This process-related circularity is a fact that biology must take into account. The process of the living takes place in normal matter, only that the latter is organized in such a way that it shows autopoietic behaviour. The autonomous encounter with reality - an encounter that is not completely causally determined - is called "cog nition" by Varela. He does not use the term in the classical sense of the cognitive sciences (which understand by "cognition" the logical operation of symbols) but rather emphasizes the living's creativity of opening up a world in interactions relative to the living system. By cognition in an autopoietic sense, organisms create relevance by separating the outside from themselves, while at the same time being dependent on it: 
In brief, the term cognitive has two constitutive dimensions: first its coupling dimension, that is, a link with its environment allowing for its continuity as individual entity; second its interpretative dimension, that is, the surplus of significance a physical interaction acquires due to the perspective provided by the global action of the organism. (Varela 1997: 81)

The transition of the physical level of energy to the level of significance happens when the organism manifests as a "whole". By this the relation of energetic exchange becomes a relation of signification on the existential background of the organism. Because the living system has an interest in keeping itself closed, it becomes dependent on the surroundings. Outward stimuli thus gain meaning in respect to the organism's needs.

The making of the self actually creates an ontological triangle: by self-confirmation, the non-self is separated off as Umwelt; and this separation opens the possibility of interaction with the Umwelt, for better or worse. The world thus gains, in the same movement by which Self and Other are divided, existential significance for the emerging self. This triadic relation can be understood as the archetype of the sign-process as construed by Peirce. In this view, the selfconstitution of the subject is always the constitution of a semiosphere. ${ }^{2}$

For an organism the world has a meaning in an existential sense, because the interactions with this world determine the fate of the living unit. This interaction is marked by a twofold difficulty, a seemingly paradoxical situation: First, the organism has to keep in the field of physico-chemical law to maintain a "coupling" with the underlying energetical structures. Second, the organism is not causally determined by the outside. It creates its behaviour by its own regulation. So the "real background" gives sense to the organism's behaviour precisely in establishing a continuous threat to it:

The difference between environment and world is the surplus of signification which haunts the understanding of living and of cognition, and which is at the root of how the self becomes one... There is no food significance in sucrose except when a bacterium swims upgradient and its metabolism uses the mole-

${ }^{2}$ An interesting point is that Peirce's triadic sign has a strong similarity to Kant's Ding an sich: the object (the signification) does not 'really' exist as such, but only arises by our encounter with the Ding an sich, that, in turn, will never show its real nature because we are slaves to our conditions of perception. Only the sign exists really (in an energetic sense) but is perceived only in that form which our body makes of the perturbation it causes. 
cule in a way that allows its identity to continue. This surplus is obviously not indifferent to the regularities and texture (i.e. the 'laws') that operate in the environment, that sucrose can create a gradient and traverse a cell membrane, and so on. On the contrary, the system's world is build on these regularities, which is what assures that it can maintain its coupling at all times. (Varela 1991: 86)

A "perturbation", in autopoietic terms, is a stimulus that interferes with the organism from the outside. It is causing the organism to react, but in a way that is determined by its inner processes and states. Hence, a stimulus is interpreted. Perturbation sensu Maturana \& Varela (1980) and sign sensu Hoffmeyer (1996) are thus identical: they are both existential interferences. Autopoiesis also provides an empirical explication of the proto-biosemiotic theory of Jakob von Uexküll (1980). When organisms are conceived of as autopoietic systems, meaning is their fundamental dimension of existence. This is the true boundary that separates the organic realm from pure matter. It is the organism's paradoxical dependence on its surroundings that lends to those surroundings an irrevocably existential value. A semiotics of the living world must be constructed on this foundation. It must be a biological theory of meaningful, natural signs qua the organisation of life that realizes its existence.

\section{Ecstasitics of cognition}

We have said that the reaction of living systems to material constraints is the unfolding of a dimension of meaning. For a living system, continued existence toward processual closure is intrinsically the subjectively absolute goal of the system. But this absoluteness is also manifested externally. A subjective impression of a perturbation, as the term was explained above, must always be connected with an expression. This observation calls for the logic of autopoiesis: Because biological self-production occurs as a material process, every signification is primarily a material one, simply because the breakdown of the process closure puts an end to life. Only by this material process the subjective perspective is obtained. Therefore, in the outer shape of autopoietic systems, meaning appears as form. As such it reveals itself in a sensually graspable manner. This means that the mode of being of 
organisms has an irreducibly aesthetic side by which precisely this mode of being becomes visible. ${ }^{3}$

The relation between inside and outside was prefigured in our definition of cognition. In cognition, meaning becomes manifest for an organism in the perspective of concern. This is always a bodily, material process in space, because the living system really exists in space and time and because the process of living is about maintaining an identity as matter. For example, an animal will react to a shock by flight, to a wound by hiding and later by bearing a scar. A tree on a steep slope will visibly force its roots into the soil. There is a general exterior aspect to autopoiesis because organic systems are embodied, because they are reacting as bodies in space to their worlds.

A system's inward reaction to a perturbation, and thus its necessary generation of meanings, shines through bodily as the system's mode of reaction to stimuli. Because we defined cognition as a system's inner-directed reaction to a perturbation and thus as the necessary generation of meanings, the system's history is a display of these meanings. The outside is the first place where meaning appears visibly. The difference between "inside" in our subjective sense and "outside" in the sense of a morphology then is only a distinction between modes of expression. "Subjectivity" in this sense is primarily meant as "concerning the perspective of cognition", and this perspective can be manifest in an inside or an outside. Or rather, it will show up both inside and outside, because neither is possible without the other.

Cognition, as the complete self-realization of a living organism, is visibly embodied. It is the transparency of an invisible inside in the outside, a level of expression within the bodily reality of coping with the world. Form is thus necessarily related to what an organism experiences from its inner perspective. The Aristotelian "soul", as the paradigm of the specific "being as such" of a phenotype and its levels of development, remains open at every moment. The cramped fists of a hungry baby, or his sleepy uncertain movements, say something about his inner perspective without being entirely capable of saying

${ }^{3}$ For Aristotle, the morphological form of an animal was indeed the expression of its anima, its "soul". It is a principle of motion inseparable from the body of plants, animals and humans, organizing matter into the form of a living being. Since the quintessence of organism lies in its form. The living aspires to it according to its own entelechy. Cf. Aristotle, De anima II, 1, 412a; Aristotle, Physik 254b. 
how he is feeling "in reality"; for this "reality" simply does not exist in a discursive way because the baby's perspective is a private one. ${ }^{4}$

This brings us to the issue of animals that have no highly centralized nervous system - a point of critique frequently raised against Jonas's claim that life is generally subjective. For subjectivity to arise, however, a central nervous system is not necessary. In understanding the interplay between autonomy and necessity, form and matter, as organic cognition on the most basic bodily level, it becomes clear that the nervous system is embedded in the physiological context as a specialized part of it, but not as something entirely different. Here the still-dominant, consciousness-centered view misses the point. ${ }^{5}$ The whole reacts to a stimulus, and its expression can perhaps be all the stronger, the less important the role of a nervous system is: think of the immense aesthetic dimension of flowers and anthozoans, the weightlessness of floating jellyfish, like the drifting of life itself - all that is an inside turned to the exterior, feeling voiced to the world.

In this view, the perennial question of how mind can causally determine the body becomes obsolete. For even a simple organism does not react causally to its environment, but rather according to its inner states, hence, according to meaning. When a protist flees chemical stimulation, there is no reason, from the protist's point of view, to admit two different processes, one intentional and one physical. We rather have to deal with a uniform biological process, in which flight behaviour is the manifestation of the meaning that the chemical substance has for the organism. This meaning is to decipher from a host of signs already on a basic biological level. Think, for example, of the speaking expression of a drying plant, or even of a Paramecium that cramps together its unicellular "body" before it dies from the picrinous acid dripped on the slide. The hermeneutics of the living that Helmuth Plessner (1975) speaks of begin already here. ${ }^{6}$

${ }^{4}$ Here we are augmenting Wittgenstein notion of "private language" with a biological dimension (already implied in Maturana \& Varela 1980). But note that a "biological privateness" is far more accessible than a purely linguistic one.

${ }^{5}$ See, e.g., Wetz (1994: 89, 194); also Schäfer (1993) and Krebs (1997). These critics seem not to be aware of the final depth of Jonas' ideas, which logically do not admit an ontological separation within the realm of the living. This also shows that it is urgently necessary to support Jonas's ontology with the more empirical and more widely-accepted findings of Varela.

${ }^{6} \mathrm{I}$ am aware that this can be only a preliminary discussion of the subject. Prima facie intuition shows a correlation between my feelings as a sentient being and the symptoms observed in the other. My reasoning here also does not mean that I deny the reality or the communicability of human consciousness. I simply believe that meaning 
Let us now return to the "expressive" dimension as seen in the pure fact of the morphological presence of living things. This sensual presence may well be the "surplus of meaning" that Varela talks about. Contrary to Heraclitus's view, nature apparently delights in showing itself. This ubiquitous sensual presence is what Gernot Böhme calls the "ecstatic character" of nature. ${ }^{7}$ It protrudes ("ex-stare") from itself and affects the senses of every being:

That nature has such an ecstatic dimension is easily proven with scientific facts... Concrete nature is full of colours, smells, full of signs and contours, there is no thing that does not show its presence and that does not contribute with its voice to the great concerto. (G. Böhme 1992: 131, transl. by A. W.)

Cognition thus becomes an aesthetic phenomenon of the first order. I define aesthetics here primarily as a theory of sensual perception relating to the concrete, sensual, and therefore subjective presence of things. Aesthetics defined in this manner is founded on an autopoietic theory of organic perception. This is in line with the original sense of the term coined by Baumgarten in the eighteenth century. Now we can enlarge upon this: In sensually perceiving natural things we can see their cognitive histories. If the ecstatic dimension says something about an organism's underlying cognition, then it speaks also about the inner dimension of life thus made visible. Such a semiotic aesthetics is therefore the key to understanding nature, to deciphering living subjective meaning, and to understanding the world thus created. Outside myself meaning becomes visible first and immediately in the aesthetic dimension, as an embodied sign of cognitive history. It is thus the most direct access to "knowledge" about the world. But this knowledge is not discursive. It is rather the "archetype of the concrete", as Jonas says (1973: 39). Sensually experienced expression is not information. It is meaning.

This brings me to another consequence of the logic of the autopoietic system. Successful autopoiesis is the achievement of life's selfapproval; it is thus the materially successful gesture of the organism's saying "yes!" to itself. The motive that is expressed in the ecstatic aspect of the living therefore must be continued existence under the aspect of its success. That means flourishing, flowering. Even the simplest form of life in its visibility shows an ecstatic moment in the most

is transparent already in many ways before - and beyond - consciousness. For us the phenomenon of life is the only immediately accessible domain, the only "knowledge" that we have directly, unaltered by the sense organs.

${ }^{7}$ Cf. Corrington (1995). 
emphatic sense of the word, as evidenced by its overflowing and transgressing its own limits.

And life as self-approval may be automatically life as beauty. In living, life celebrates itself. Only as an emphatic gesture of selfapproval can it be life, since it always has to confirm its existence in order to assure its continuation. ${ }^{8}$ Can we postulate that the beautiful has its logical place as the necessary formal counterpart of achieved autopoiesis? Can we say that the realization of the living not only has a beautiful component, or can be treated under an aesthetic aspect, but that it rather is beauty in its essence? ${ }^{9}$

\section{Nature as embodied feeling}

In ascribing a decipherable meaning to the exterior aspect of natural things, we methodologically approach the classical semiotic practices of antique medicine and medieval theology. In a way our semiotic proposal is an organic hypothesis concerning what Hans Blumenberg (1981) calls the "legibility of the world", referring e.g. to the symbolic universe in Renaissance alchemy or in medieval belief. Nonetheless, our approach does not derive from any culturally established cosmos of signs, but rather from an empirical look at cognition.

Living nature can act as a reservoir of symbols, because it implies continuously its organic background. By this, it shows a transparency of its functioning conditions. In living form the laws of a general conditio vitae thus appear in a nondiscursive manner, as expression: as expression of the tendency to variety, manifoldness, plenitude - to precarious, utopic plenitude. The autopoietic theory of the organism engenders a theory of organic expression as a necessary consequence. This reminds of the medieval way to speak of macro- and microcosm (Böhme 1988): From an autopoietic viewpoint the understanding of

${ }^{8}$ See also Jonas in Wetz (1994: 141): "In its desire for more life, life is more than life because it contains a 'yes to life' concerning itself. The more complex an organism is, the more intensively it experiences its inner dimension, and the more 'emphatically' it approves itself" (transl. A.W.).

${ }^{9}$ This comes close to the kind of "unlocated sense organ" Bateson (1988) saw in the flowering meadow. The meadow for him danced an endless dance: the history of embodiment of meanings in the interplay between the self-realizing individuals and their Umwelten, an ecstatic dimension of feeling transposed on the outside. This embodied cognition is what Bateson called mind: the unfolding of a dimension of meaning by the history of auto-regulation of a living system. 
living form is possible because the receiver is himself nothing different than the universe sending out signs; because organic nature is a symbolic expression of the symbolically operating organic subject.

Nature as a whole is symbolically pregnant, in the sense of Ernst Cassirer. The sensual effect of natural forms is corporeally the same as their symbolic understanding. This equates with the Goethean idea of the "Urphänomen" which is something that acts as a symbol because it empirically has the symbolized qualities (as e.g. the magnet for attraction and rejection). ${ }^{10}$

This leads to a radical consequence in which the mind-body problem seems to be overcome semiotically. The correspondence between mind - the interior subjective perspective - and body is itself already a symbolic relationship. Meaning and value as correlates of the interior perspective become visible in the body. This biosemiotic interpretation joins how Cassirer argues:

The relation between body and soul represents the archetype and first model for a genuinely symbolical relation ... Here neither an inside nor an outside is at the origin, neither a before nor an afterwards, a causing force or a caused effect. (Cassirer 1977-1982, vol. 3: 117; translation A.W.)

Mind is a symbol for the body because mind - the subjective experience - is the meaning of the experience mediated by the body. This relation mirrors the way the interior perspective is the meaning of the body's encounter with situations.

If we take nature as an assembly of bodies and the body as a part of nature, then we can extend this finding; then "soul" in Cassirer's sense stretches out as the whole of animate nature lying before us. Nature thus is the outside of an organic inside, hence it is also our inside turned out; its expression is our intentionality. At the same time, from the expressiveness lying before me, another inside can be experienced as an outside. A subjective experience with an Other, who is not different from me in its basic situation, becomes aesthetically transparent. And only thus does it becomes real: the inside, or feeling, is

\footnotetext{
${ }^{10}$ The concept of a natural symbolization process presented here is far more precise than the American Transcendentalists' view, e.g. in Emerson's dictum, "Things admit of being used as symbols, because nature is a symbol, in the whole and in every part" (1951: 269). Transcendentalism started from the romantic supposition that spirit manifests in nature and is symbolized through it. The present approach contents itself with biological observation. Nature is not a transcendental symbol of the spirit beyond by downward causation. Rather spirit - organic cognition - works by upward causation, creating signs and symbolic pregnancy through the realization of the living (Weber and Varela, in preparation).
} 
only possible as the cognitive or behavioural dimension of an outside, of an embodied form. Both are fundamentally the same, in the sense that they form the matrix of one biological individuality.

In this view nature is legible as an ecstatic emanation, as an exteriorization of inner experience. The organic world around us is thus identical with the emotional world inside us. Nature reflects the latter in a kind of familiar, but nondiscursive mirror and thus expresses before me what is inside of me, but what can gain reality only by being expressed (Weber 1998). In this respect, biodiversity is not only the illustration of an endless variation on functionality, but is also an expressive phenomenon of the first order. It is the presence of manifold ways of organic experience. And only by means of this existential subjectivity does the semiosphere come into being.

\section{Ecosemiotics:}

\section{Nature as a necessary symbol for human experience}

The semiotic threshold is transgressed by the generation of value due to the self-maintenance of an autopoietic system. Therefore in its foundations semiotics is always biosemiotics. Cultural semiotics is working as an extension of the same principles which biosemiotics basically generates in organism, thus creating a semiosphere that is partly, but not totally independent from bodily foundations. The prefix "bio-" viz. "cultural" designates the respective system engendering semiosis: this can be a biological or a cultural structure (which would be called a "discourse" or "dispositif", cf. Foucault 1990).

We have to speak of "ecosemiotics" in any case the relation to the external environment is concerned. First this is just biology: What in classical terms is described by the biological subdiscipline of ecology would be ecosemiotics in a biosemiotic approach - as physiology in a biosemiotic view has become endosemiotics (Uexküll et al. 1993), zoology zoosemiotics (Sebeok 1963) and botany phytosemiotics (Krampen 1992). Therefore, some biological relations of the human species to the environment may be called ecosemiotic because in principle they are biosemiotic.

We can also speak of ecosemiotics as a subgroup of cultural semiotics, e.g. when the sign system concerns man's relationship towards nature (as e.g. in the "natural semiotics" of Paracelsus, see Blumenberg (1981), Böhme (1988), or, for another example, Bateson's 
"Ecology of Mind" (1988), a work, which is by the way groundbreaking semiotics). This is the far more interesting point: Maybe the truly ecosemiotic part of cultural semiotics is where the junction lies between biological and cultural generation of signs, and where hence the access to the mind-body problem can be found.

Cultural ecosemiotics then is the expression of man's organic nature in cultural terms. In this respect, the cultural universe of archaic people like the Australian aborigines rests nearly completely ecosemiotic - cosmological, territorial, social and historical structures being expressed via paintings or songs "representing" animals, plants, and landscapes (Lévi-Strauss 1968, Morphy 1991). I therefore claim that ecosemiotic thinking reveals the fact that in the symbolic cosmos of culture organic nature is the strongest symbol to represent the human organic conditio vitae (Weber, in preparation).

Culture in its deep roots is always ecosemiotic. Culture is an intensification of the basic paradoxical situation of the closed organic system that despite its closure has to allow a flux of the world through its confines. We have seen with Cassirer that "interiority", hence mind, can be considered as the meaning of the existential embodied realities. In a parallel movement, the embodied organic realities outside, are symbolic for the human interior perspective. This may account for the obsession with nature in early culture.

The first stage of this archaic functioning of natural symbols is a kind of metonymic effect, that has been emphasized by various authors working about primitive stages of symbolism. Especially Cassirer has seen the important role of ritual involving the body's senses in the symbolic cosmic religions of primitive people; a finding that has been confirmed empirically by the fieldwork of various authors (Morphy 1995, Layton 1995).

In a concrete manner then the inner space of experience finds its synechdochetic extension in the real spaces of nature. Only by the experience of the living depth of nature the own inner universe the poet Rilke is speaking of as "intensified sky" becomes accessible. Another prime metaphor for this inner space is the sea, as have shown authors like Melville, Conrad, and, recently, Hamilton-Paterson. For there is an inner relationship of space that stands apriori to the real spaces of the world. This is the space of the inner experience, a valueor meaning-space that measures and expresses real outside spaces in its terms, and that lays a metaphorical and synaesthetic basic grid on the world, with its meshes determined by the existential values of organic meaning. This primordial space is not the body. It is the space of 
organic existence, the absolute space of existential meaning. This space is real not as the Euclidean topography we conceive the world of, but as the synaesthetic and ecstatic space of the whole nature.

If nature acts as the main reservoir of organic symbols, and if these symbols are essential for grasping our own interior in a concrete, embodied form, then the presence of natural forms is an inevitable condition for us to fully understand ourselves. The hypothesis that there is a deep meaning in the experience of natural beauty is echoed by many recent works in cultural studies that show man's obsession with forests, trees, lakes, animals, and so on throughout history (e.g., Schama 1996; Böhme \& Böhme 1996). Oelschlaeger (1991) has observed that people who dedicate themselves to preserving wilderness are trying to protect this symbolic cosmos, and not a particular landscape.

The ecosemiotic lesson that we can draw from this might be that living nature really is a symbol for something most important in us. By being transparent in itself, living nature reveals the functioning of the cosmos that has brought forth life as the paradigm of the selfbearing, self-producing, flowering plenitude of a fragile and precarious equilibrium that is always doomed to fail, but that at the same time will always be replaced by new growth. This is the only adequate model of the soul. The destruction of nature thus has a symbolic counter effect on that which have prospering organic beings. In destroying other creatures as the resources of self-growing life, we say goodbye symbolically to the principle of plenitude. ${ }^{11}$

\section{References}

Aristotle. De anima II, 1, 412a.

- Physik 254b.

Bateson, Gregory 1988. Ökologie des Geistes. Frankfurt am Main: Suhrkamp.

Blumenberg, Hans 1981. Die Lesbarkeit der Welt. Frankfurt am Main: Suhrkamp. Böhme, Gernot 1992. Natürlich Natur. Frankfurt am Main: Suhrkamp.

Böhme, Gernot; Böhme, Hartmut 1996. Feuer, Wasser, Erde, Luft: Eine Kulturgeschichte der Elemente. München: C. H. Beck.

Böhme, Hartmut 1988. Natur und Subjekt. Frankfurt am Main: Suhrkamp.

Böhme, Hartmut; Müller, Lothar; Matussek, Peter 2000. Orientierung Kulturwissenschaft: Was sie kann, was sie will. Reinbek bei Hamburg: Rowohlt.

11 This work has been funded by scholarships from the Deutsche Bundesstiftung Umwelt (DBU) and the French Government. 
Cassirer, Ernst 1977-1982. Philosophie der symbolischen Formen. Darmstadt: Wissenschaftliche Buchgesellschaft.

Conrad, John 2000. Lord Jim: Eine Geschichte, München: Piper.

Corrington, Robert S. 1995. Ecstatic Naturalism: Signs of the World. Bloomington: Indiana University Press.

Emerson, Ralph W. 1951. The Poet. In: Emerson's Essays. New York: Harper and Row, 261-291.

Foucault, Michel 1990. Einleitung zu Der Gebrauch der Lüste. In: Engelmann, Peter (ed.), Postmoderne und Dekonstruktion: Texte französischer Philosophen zur Gegenwart). Stuttgart: Philipp Reclam jun., 84-107.

Glacken, Clarence J. 1967. Traces on the Rhodian Shore: Nature and Culture in Western Thought from Ancient Times to the End of the Eighteenth Century. Berkeley: California University Press.

Goethe, Johann Wolfgang von 1998. Gesammelte Werke. Hamburger Ausgabe. München: dTV.

Hamilton-Paterson, J. 1995. Seestücke. Stuttgart: Klett-Cotta.

Hoffmeyer, Jesper 1996. Signs of Meaning in the Universe. Bloomington: Indiana University Press.

Jonas, Hans 1973. Organismus und Freiheit: Ansätze zu einer philosophischen Biologie. Göttingen: Vandenhoeck und Ruprecht.

Krebs, Angelika (ed.) 1997. Naturethik: Grundtexte der gegenwärtigen tier- und ökoethischen Diskussion. Frankfurt am Main: Suhrkamp.

Krampen, Martin 1992. Phytosemiotics revisited. In: Sebeok, Thomas A.; Umiker-Sebeok, Jean (eds.), Biosemiotics: The Semiotic Web 1991. Berlin: Mouton de Gruyter, 213-219.

Kull, Kalevi 1999. Biosemiotics in the twentieth century: A view from biology. Semiotica 127(1/4): 385-414.

Lévi-Strauss, Claude 1968. Das wilde Denken. Frankfurt am Main: Suhrkamp.

Langer, Susanne K. 1953. Feeling and Form. New York: Scribner's.

Layton, Robert 1995. Relating to the country in the Western Desert. In: Hirsch, Eric; O'Hanlon, Michael (eds.), The Anthropology of Landscape. Oxford: Clarendon Press, 210-231.

Maturana, Humberto R.; Varela, Francisco J. 1980. Autopoiesis and Cognition: The Realization of the Living. Boston: Reidel.

Melville, Herman 1977. Moby Dick. Zürich: Diogenes.

Morphy, Howard 1991. Ancestral Connections: Art and an Aboriginal System of Knowledge. Chicago: University of Chicago Press.

- 1995. Landscape and the reproduction of the ancestral past. In: Hirsch, Eric; O'Hanlon, Michael (eds.), The Anthropology of Landscape. Oxford: Clarendon Press, 184-209.

Oelschlaeger, Max 1991. The Idea of Wilderness: From Prehistory to the Age of Ecology. New Haven, CT: Yale University Press.

Peirce, Charles S. 1968. The Collected Papers of Charles Sanders Peirce. Cambridge, MA: Harvard University Press.

Plessner, Helmuth 1975. Die Stufen des Organischen und der Mensch. Berlin: Mouton de Gruyter. 
Schäfer, Lothar 1993. Das Bacon-Projekt: Von der Erkenntnis, Nutzung und Schonung der Natur. Frankfurt am Main: Suhrkamp.

Schama, Simon 1996. Der Traum von der Wildnis: Natur als Imagination. München: Kindler.

Schrödinger, Ernst 1944. What is Life? The Physical Aspect of the Living Cell. Cambridge: Cambridge University Press.

Sebeok, Thomas A. 1963. Review of communication among social bees; porpoises and sonar; man and dolphin. Language 39(3): 448-466.

Steiner, George 1991. Réelles présences: Les arts du sens. Paris: Gallimard.

Uexküll, Jakob von 1980. Kompositionslehre der Natur. Frankfurt am Main: Ullstein.

Uexküll, Thure von; Geigges, Werner; Herrmann, Jörg M. 1993. Endosemiosis. Semiotica 96(1/2): 5-51.

Varela, Francisco J. 1991. Organism: A meshwork of selfless selves. In: Tauber, Alfred I. (ed.), Organism and the Origins of Self. Dordrecht: Kluwer Academic Publishers, 79-107.

- 1997. Patterns of life: Intertwining identity and cognition. Brain and Cognition 34: 72-87.

Weber, Andreas 1998. Der sprachlose Spiegel. Deutsches Allgemeines Sonntagsblatt 18: 27-29.

Weber, Andreas; Varela, Francisco J. (in preparation): Life after Kant: Natural purposes and the autopoietic foundations of biological individuality.

Wetz, Franz J. 1994. Hans Jonas zur Einführung. Hamburg: Junius.

Wilson, Edward O. 1995. Der Wert der Vielfalt: Die Bedrohung des Artenreichtums und das Überleben des Menschen. München: Piper.

\section{Познание как выражение: автопойэтические основания эстетической теории природы}

Предлагается эстетическая теория природы, опирающаяся на биосемиотическое описание живой природы, которое в свою очередь выводится из автопойэтической теории организмов (Ф.Варела). Результатом реакции на материальные ограничения автопойэтической системы является открытие измерения значения. Во внешнем гештальте автопойэтических систем значение является в виде формы. Существование организмов имеет неотъемлемую эстетическую сторону, посредством которой это существование становится видимым. Природа, таким образом, проявляет известную прозрачность по отношению к своему функционированию: посредством своей телесной саморепрезентации организмы недискурсивно птроявляют знаки conditio vitae. Значит, живые существа всегда проявляют некоторую экспрессивность как неизбежную часть бытия живым. Это можно назвать и экстатическим измерением (Г. Беме, Р. Коррингтон). Автопойэзис напоминает идею Парацельса о 
signatura rerum (К. Глакен, Х. Беме): природа прозрачна не потому, что она дигитально организована в виде текста или кода, а скорее потому, что она аналогово представляет вызываемую автопойэзисом интенциональность. Природа в целом как "живая форма" (С. Лангер) символизирует органическую интенциональность. Основное значение защиты природы, таким образом, - обеспечение "истинного присутствия" нашей души.

\section{Tunnetus kui väljendus: looduse esteetilise teooria autopoieetilistest alustest}

Esitan oma artiklis looduse esteetilise teooria, tuginedes eluslooduse biosemiootilisele kirjeldusele, mis omakorda on tuletatud organismide autopoieetilisest teooriast (F. Varela). Autopoieetilise süsteemi reaktsiooni tulemuseks materiaalsetele piirangutele on tähenduse mõõtme teke. Autopoieetiliste süsteemide väljapoolses Gestaltis ilmub tähendus vormina ja avaldab end sellisena meeltega haarataval moel. Organismide olemisel on taandamatu esteetiline külg, mille läbi see olemine saab nähtavaks. Loodus ilmutab seega teatavat läbipaistvust oma funktsioneerimise suhtes: oma kehalise eneseesituse kaudu ilmutavad organismid mittediskursiivsel viisil conditio vitae märke. Seega ilmutavad elusolendid alati algsel tasemel olevat väljenduslikkust kui elusolemise vältimatut osa. Seda võib nimetada ka looduse ekstaatiliseks dimensiooniks (G. Böhme, R. Corrington). Autopoieesis sarnanab selle poolest vaatega, mis meenutab Paracelsuse ideed signatura rerumist (C. Glacken, H. Böhme): loodus ei ole läbinähtav mitte seetõttu, et ta on digitaalselt organiseeritud teksti või koodina, vaid pigem seetõttu, et ta esitab analoogselt autopoieesise poolt esile kutsutavat intentsionaalsust. Loodus tervikuna kui "elav vorm" (S. Langer) sümboliseerib seega orgaanilist intentsionaalsust. Looduskaitse kõige põhimisem tähendus on seega meie hinge "tõelise kohalolu" tagamine. 